\title{
Enhancing Student Active Learning in Consumer Behaviour Class Using 5E Learning Cycle: A Conceptual Paper
}

\author{
*YATY SULAIMAN ${ }^{1}$, MARIA ABDUL RAHMAN ${ }^{1}$, NIK KAMARIAH NIK MAT ${ }^{1}$ \\ ${ }^{1}$ School of Business Management, College of Business, Universiti Utara Malaysia, Kedah, \\ MALAYSIA
}

\begin{abstract}
E learning cycle was suggested as a better option for students' learning and has brought a positive impact on students learning education, particularly with theory and practice components. These method of learning is a student's centre oriented learning model which solely prioritize on students own experiences, creates active participation and built creative critical thinking skills. 5E learning cycle consist of engagement, exploration, explanation, elaboration, and evaluation. This study is intended to determine students' perceptions of $5 \mathrm{E}$ learning cycles in their learning activity and to explore the impact of 5E learning cycles towards student's active learning. The discussion is based on the information gauged from an estimated number of 60 undergraduate students who will be enrolling in BPMM3013 Consumer Behaviour Class in UUM. Data will be collected qualitatively from various sources such as students' reflections, lecturer's reflections, peer feedback, lecturer's feedback, and focus group interview. Meanwhile for quantitative method, a survey will be developed through Google form. The data will be analysed using transcribe technique and regression analysis.
\end{abstract}

Keywords:- 5E learning cycle, active learning, consumer behaviour

Received: February 8, 2020. Revised: May 20, 2020. Re-revised: May 31, 2020. Accepted: June 6, 2020. Published: June 15, 2020.

\section{Introduction}

A success or failure of an education goals depends on how the learning process experienced by the students in the classroom as learning is the most basic activities in the whole process of education. In any formal education, most of learning activities are conducted in a classroom, having a built-in environment where formal learning process takes place. These conventional approach was characterised by teacher-centred. . For the instructor, classroom time is a golden opportunity to meet face to face with the students, delivering the teaching material effectively with the aim to ensure that students are learning what is being taught. On the other hand, the students are expected to be presence on time and participate actively to absorb, seek and apply the skill and knowledge shared in the classroom or other learning activities. These complementing engagements between lecturers and students do generate conducive classroom environment (Abdullah, Abu Bakar and Mahbob, 2012) [1].
In recent years, new methods and techniques have been flourished in education system construct and deliver knowledge in different situations for individuals of these modern technology equipped world. the teaching methods using the context of energy change was structured in such a way that it follows the characteristics of each phase in the 5E inquiry learning model, namely engage, explore, explain, elaborate (expand), and evaluate. In each phase of these 5E-learning model, the learner itself will be actively involving in the learning process, which also promotes conceptualization of his own concepts (Ergin et al., 2007) [2].

It is an important context where both students and instructor come into contact to share information in their quest for knowledge. A conducive classroom environment involved two-way interaction between students and instructors.

Conducive classroom environment emphasizes cooperation and openness between teachers and students. A comfortable interaction between the teachers and students will produce 
positive learning relationships in the classroom and contribute to effectiveness of the learning. Teachers will be able assess changes in students' behaviour and understand the needs of students in the classroom. Meanwhile, students who enjoy a better relationship with their teachers are more likely to feel free to discuss their ideas, more willing to engage in discussions. Positive relationships among teachers and students encourage students to have a democratic voice (Torney-Purta, Lehmann, Oswald, \& Schulz, 2001) [3]. This type of classroom environment will stimulate learning and makes both the instructor and students feel satisfied, which eventually leads to effective learning process. According to Wade (1994 as cited in Abdullah et al., 2012) [4], most students can obtain the benefits such as the enjoyment of sharing ideas with others and learn more if they are active to contribute idea in class discussion. Effective learning process occurred when both instructors and students interact and actively participate in the learning activities. 5E-learning cycle built a positive vibration on students learning, motivation, achievement, construction of knowledge, attitudes toward the course, satisfaction, and creates a higher-order thinking skills among them. Senan (2013) [5] delivers that the technology-enriched $5 \mathrm{E}$ learning cycle is a good tool for students to move fast forward and acquire 21st-century skills as well as for teachers to teach a specific unique concept. Nevertheless, as we often hear from the academic world, students still do not actively participate or become passive in the classroom despite encouragements and use of various teaching methods by the instructors to stimulate active participation from the students (Duran \& Duran, 2004) [6].

Results from an instructor's observation students in BPMM3013 Consumer Behaviour class indicated that majority of them are passive learners and almost none of them are willing to answer the questions given by instructor voluntarily. By contrast, the lecturer needed to call the name of students to give their answer or opinion on case study given. This happened when a normal and traditional teaching method delivered by lecturer by distributing case studies, asking them discuss, present and to submit the reports at the end of semester. Using a learning cycle approach in the classroom helps to facilitate inquiry practices because learning cycles focus on constructivist strategies and emphasize the explanation and investigation of real scenario, the use of evidence to back up conclusions. Duran and Duran (2004) [7] argued that inquiry needs to be a central strategy of all curricula. Similarly, study by Soon, Meng and Jiong (2017) [8] showed that students are actively giving solutions on case given upon the 5E intervention. In other words, the students need to be active learner in order to graduate as a holistic graduates in future. Therefore, this study aimed to explore the pedagogical impact of learning by an adapted the 5E Instructional Model as intervention. Specifically, the study aimed to explore the change in Consumer Behaviour students' ability to engage in employing alternative solution strategies for their case study given upon the intervention. The discussion is based on the information gauged from the students during focus group interviews and survey technique intended to explore what are the reasons that motivate students to speak up in classroom.

\section{Literature Review}

Simply defined, learning is acquiring new or modifying existing knowledge, skills or behaviours. Therefore, if learning is defined as quest for knowledge, skills or behaviours, then students need to be active in that quest. Behaviours of students in classroom may vary from passive to active participations. They may just sit quietly, taking notes, listening, doing something else, or asking questions, giving opinions, or answering questions posted (Mohd Yusof, et al 2011 [9]; Hussein, 2010 [10]; Bas, 2010) [11]. There are various types of classroom behaviours. An active learners, engage actively by playing the roles of information seekers in the classroom. The acts of asking questions, giving opinions or simply answering questions posed by the instructor or fellow students are examples of an active type of classroom participation. According to Davis (2009) [12], student's enthusiasm and willingness to participate in a classroom through these verbal engagements will create a conducive classroom environment.

Past studies have shown there are several factors influencing student's participation in the learning process. The first factor lies in the personality of the students. Students with high 
self-efficacy showed better academic achievement and active participation in the classroom (Pajares, 1996 [13] \& Schunk, 1995) [14]. High students' self-efficacy will enhance their confidence level to become more active and speak more in the classroom, as mentioned by (Rahil, Habibah, Loh, Muhd Fauzi, Nooreen, Maria Chong, 2006) [15] selfefficacy trait with displaying with more of curiosity and exploring urge would motivate them to become more active and positive reciprocity. Meanwhile, students with selflimitations will become passive in classroom, loss of focus and fear of offense (Siti Maziha, Nik Suryani \& Melor, 2010) [16]. Lower levels of self-confidence, not prepared before the class, fear of failing to show their intelligence, fear that their answers will be criticized by the lecturers and the feelings of confusion will make them to less engage in the classroom discussions (Fassinger, 1995 [17]; Gomez, Arai \& Lowe, 1995) [18].

A total of 31 studies which were published or unpublished nationally or internationally between 2006 and 2016, which were applied in science lessons, designed in experimental design, with quantitative data combined. Cakir, 2017 [19] used a total number of 2256 of samples to determine its effect on academic achievement. Based on random effects model, it has been determined that the overall effect size of the studies was found to be 1,017 and $\mathrm{ES}=1,268(\% 95 \mathrm{CI}, \mathrm{SE}=0,128)$ at a confidence interval of 1,518 which has a very broad level of effect according to Cohen (1988) classification. According to the findings of the study, 5E learning model was very effective on academic achievement compared to traditional teaching method.

Gillies, (2003) [20] research on the forming of cooperative small group works, communication skills, learning and behaviour determined that cooperative groupworks clearly appeared and students will achieve greater success and motivation with cooperative method than working alone. K1lavuz, (2005) [21] comparing the influence of 5E Learning Cycle Model and traditional model on a constructivist method on the understandings of 10th grade students towards subject of acid found that students' attitudes of two groups towards chemistry improved equally. Bozdon, (2007) [22] did their research on 'Opinions of the Science teacher candidates on the viability of 5E Learning Cycle Model", through a survey data collection from students' answers to the open-ended questions about the issue. Research found from teacher candidates that there are more positive sides of the model but there are also some difficulties in practising the learning model such as lack of equipment and time, overcrowded classrooms and teachers' lack of information. Hirça, (2008) [23] from his work named "Examining of the effect of the materials developed about the issue of "Work, Power and Energy" depending on 5E Learning Cycle Model to the Conceptual Change", noticed that constructivist approach is more efficient than traditional approach to understanding topic. Liu et. al, (2009) conducted a study on students' performances towards 5E Learning Cycle to design mobile natural-science learning activities, examine students' performances of learning aquatic plants, and explore students' perceptions towards these learning activities. The outcome of their studies is shown as below:

The knowledge test in Table 1, performed a ttest to compare the mean scores students received in the knowledge test before and after students' engagement in learning activities. Results indicates students' mean scores (26.04) after learning activities were significantly greater than students' mean scores (10.30) before learning activities $(\mathrm{p}<$ .001 ). This test confirmed that students' knowledge of aquatic plants increased, identify the correct aquatic-plant terms and corresponding plants types better after the mobile learning activities.

Table 1. Students' knowledge test scores regarding aquatic plants before and after

\begin{tabular}{lcccccc} 
learning & \multicolumn{3}{c}{ activities } & & $(\mathrm{N}=46)$ \\
\hline & $\begin{array}{c}\text { Before } \\
\text { learning } \\
\text { activities } \\
\text { Mean }\end{array}$ & \multicolumn{4}{c}{$\begin{array}{c}\text { After } \\
\text { learning } \\
\text { activities }\end{array}$} \\
& Mean & SD & $T$ \\
\hline $\begin{array}{l}\text { Knowledge test } \\
\text { of aquatic plants }\end{array}$ & 10.3 & 0.87 & 26.04 & 1.81 & 11.483 \\
\hline$* * * * .001$ & & & & &
\end{tabular}

Results of the t-test in Table 2 indicate students' scores after learning activities $(M=19.04)$ were significantly greater than students' test scores before learning activities $(\mathrm{M}=15.63)(\mathrm{p}<.001)$ in the understanding test on aquatic plants. This result shows that 
students' understanding of aquatic plants increased after their engagement in the learning activities.

Table 2. Students' understanding test scores regarding aquatic plants before and after learning activities $(\mathrm{N}=46)$

\begin{tabular}{|c|c|c|c|c|c|}
\hline & \multicolumn{2}{|c|}{$\begin{array}{c}\text { Before } \\
\text { learning } \\
\text { activities }\end{array}$} & \multicolumn{2}{|c|}{$\begin{array}{c}\text { After } \\
\text { learning } \\
\text { activities }\end{array}$} & \multirow[b]{2}{*}{$T$} \\
\hline & Mean & $\mathrm{SD}$ & Mean & $\mathrm{SD}$ & \\
\hline $\begin{array}{l}\text { Understanding test } \\
\text { on aquatic plants }\end{array}$ & 15.63 & 3.41 & 19.04 & 2.67 & 7.658 \\
\hline
\end{tabular}

\subsection{Learning Cycle}

Variety of educational models have been developed and implemented in today's academic at different levels of teaching in order to transfer the increasing fund of knowledge to the students in the most effective way. The focus was to increase the effect of teaching and learning. Learning cycle is an accessible way of expressing both theories and practise from an experiential knowledge. The learning cycle is a student-cantered model where the learning process becomes more real as it prioritizes real experience, and train a student to become active, critical and creative (Wahyuni et al., 2013) [24], researcher has also added that this type of learning is fun, student-centered and provide appropriate learning resources. Supriyatman and Amiruddin, (2014) [25] has added that learning cycle provides an opportunity for students to express their understanding, previous knowledge and the opportunity to discuss and debate their ideas, thus developed a higher level of thinking, and good approach to study. Learning cycle approach helps students to make sense of the ideas, improve their reasoning, and increase their engagement in the class.

\subsubsection{E Learning Cycle}

$5 \mathrm{E}$ learning cycle is attempted to pull the students' attention and reveal the preliminary information while the teachers gets the opportunity to understand the current concepts and performance of the students. These model would allow students to discover and acquire new knowledge and most importantly encourage them to be competent in various aspects, cognitive, affective and psychomotor learning activities. The important message is to not to let the students find the right answer, instead to encourage them to put forward different ideas while improving their ability to ask questions. Duran and Duran (2004) [26] says that using a $5 \mathrm{E}$ learning cycles approach in the classroom helps to facilitate inquiry practices as learning cycles focus on constructivist strategies and emphasize the explanation and investigation of real scenario, the use of evidence to back up conclusions. Senturk and Camliyer (2016) [27] disclosed that many fields of education at the moment, especially in physical and technological educations, use 5E learning cycles approach. The process is defined five " $E$ ". For this study, the 5 Es' were adopted. These represent the verbs engage, explore, explain, elaborate and evaluate as shown in Figure 1 below. Based on these selected past studies and literature, it can be conclusively proven that being active in classroom discussion will make the students to learn more. However, the instructor and the education provider must take into consideration the factors that stimulate or hinders the students to be active learners in the classroom.

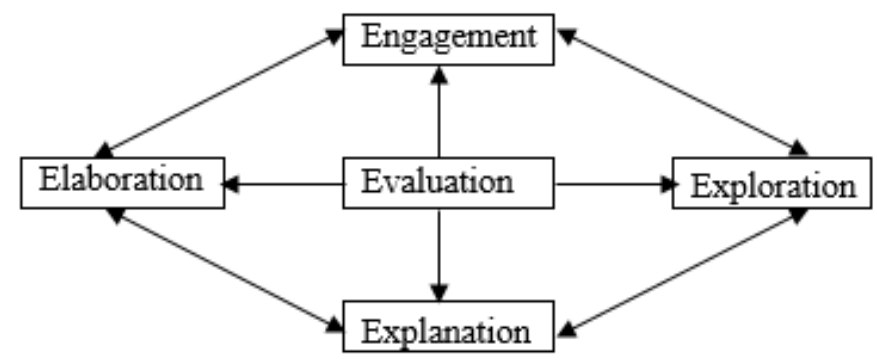

Figure 1 The 5E Instructional Model by Duran \& Duran, 2004

\subsubsection{Engagement}

The first stage of the 5E learning cycle is engagement. Instructors will involve students in discussion and explore their ideas to learn situations with prior knowledge. Instructors will support students in the activities, questions, or challenges occurred and encourage deep thinking. The lesson provides the opportunity for teachers to monitor and figure out what students already know, their understanding about the topic and concepts to be developed. The learners also has the opportunity to consider what his or her current 
ideas and thoughts are about the topic. This stage is designed to;

- Finds students' curiosity and generate interest

- Determine students' current understanding

- Offer students to raise their own questions

- Encourage students to compare their ideas

- Enable teachers to assess students understanding

\subsubsection{Exploration}

The second stage of the 5E learning cycle is exploration offering students the chance to ask and answer their own questions. Students investigate and experiment the nature of questions and draw conclusions based on observations and data. This lesson provides a common set of experiences within students to construct their understanding. More than that, there is no right or wrong at this stage; all outcomes are a chance to learn something new. At this stage, students will be;

- Engage with materials and ideas through classroom and small-group discussions

- Think through different ways to solve a problem or frame a question

- Obtain a common set of experiences, enables them to compare results and ideas with their classmates

- Observe, describe, record, compare, and share their ideas and experiences

- Express their understanding of questions

\subsubsection{Explanation}

Explanation stage provides opportunities for students to connect their previous experiences with current learning to come up the main ideas of the module. It gives students the opportunity to describe their understanding of concepts, developing their ideas and describing the process under study. At this stage, students must determine for themselves what is important to say and the best way to communicate their ideas. This stage encourages students to;
- Explain concepts and ideas (in their own words)

- Listen to and compare the explanations of others with their own

- Involved in student-to-student interaction in which they share their thoughts and thinking to others and debate their ideas

- Alter their ideas and current understanding with what they previously thought

\subsubsection{Elaboration}

Elaboration catches the fourth stage of $5 \mathrm{E}$ learning cycle involving development, expansion, growth, and progress. Students apply or extend previously introduced concepts to new situations deepen their understanding. Students will be challenged by instructors to find out their understating level. This stage involving;

- Making a conceptual connections between new and former experiences

- Connect ideas, solve problems, and apply their understanding to a new situation

- Draw reasonable conclusions from evidence and data

- Deepen their understanding of concepts and processes

- Communicate their understanding to others

\subsubsection{Evaluation}

Evaluation is the final stage of $5 \mathrm{E}$ learning cycle giving students the chance for selfassessment. This stage provides teachers with information to evaluate students' progress toward the lesson objectives. This stage provides a summative assessment of what students know and can do. At this stage, students will have the opportunity to;

- Demonstrate their understanding and how well they can apply their knowledge to carry out their own

- Share their current thinking with others

- Assess their own progress by comparing their current understanding with their prior knowledge 
- Ask questions that take them deeper into a concept

A sample of explanation of these processes are shown in Table, whereby a physical education teacher who wants to teach basic concepts about the human physiology such as heartbeat, breath, fatigue, etc.

Table 3. Sample Lesson Plan (Physical Activity Habit)

\begin{tabular}{|c|c|}
\hline \multicolumn{2}{|r|}{ Physical Activity Habit } \\
\hline Sub-Learning Domain & Relationship between Physical Activity and Circulatory System \\
\hline Learning Objectives & Developing evaluable information about Physical Activity and Circulatory System \\
\hline Course Time & 1 hour \\
\hline Skills & Reasoning, overarching \\
\hline Gains & Learning heartbeat, using in social life \\
\hline Methods and Techniques & Examination and exploring, learning by doing \\
\hline \multicolumn{2}{|r|}{ Engaging } \\
\hline $\begin{array}{l}\text { 1. "Which organs do we ha } \\
\text { 2. "Where is the heart and } \\
\text { These questions make a sensation }\end{array}$ & $\begin{array}{l}\text { Teacher asks questions as follows; } \\
\text { e most important of them?" } \\
\text { f it?" } \\
\text { tt is the heartbeat?, Why do people get tired?, etc.). }\end{array}$ \\
\hline \multicolumn{2}{|c|}{ Exploring } \\
\hline \multicolumn{2}{|c|}{$\begin{array}{l}\text { Teacher asks students to run } 2 \text { tours round the school garden. After, requests students to feel their heart beat and asks these questions; } \\
\text { 1. "Are you feeling your heartbeat?" } \\
\text { 2. } \\
\text { 3. "Do you know why your hearth beat is faster?" } \\
\text { tell a story about these situations. }\end{array}$} \\
\hline \multicolumn{2}{|c|}{ Explaining } \\
\hline \multicolumn{2}{|c|}{$\begin{array}{l}\text { Teacher wants students to run } 5 \text { tours around the school garden at this time. After heartbeats of students } \\
\text { 1. } \\
\text { 2. "How many is your heartbeat?" } \\
\text { 3. "Did you feel reactions we talked before?" } \\
\text { 4. "Are you tired and / or thirsty?" } \\
\text { 5. "Do you want to play a game or do physical activity tirelessly?" } \\
\text { Teacher lets them think critical and ask questions. So, teacher provides them with a clear understanding. }\end{array}$} \\
\hline \multicolumn{2}{|c|}{ Elaborating } \\
\hline \multicolumn{2}{|c|}{$\begin{array}{l}\text { Teacher gives them chance to use their knowledge and asks questions for reinforcement; } \\
\text { 1. "Who is your favorite athlete?" } \\
\text { 2. } \\
\text { 3. "What do you think that these athletes are tired when they run or do physical activity as much as you are?" } \\
\text { Teacher lets them think critically and answer the questions. After then students are required to discuss among themselves about relationship between } \\
\text { physical activity habits and heartbeat. Finally, the teacher teaches the relationship between these concepts so that these concepts will be thoroughly } \\
\text { learned by the students. }\end{array}$} \\
\hline \multicolumn{2}{|c|}{ Evaluation } \\
\hline $\begin{array}{l}\text { his stage, the students should } \\
\text { aposition about which activity } \\
\text { physical activity habits of the }\end{array}$ & $\begin{array}{l}\text { onship between physical activity habits and circulation system. Teacher wants them to write a } \\
\text { arly and talk about it with their families. Teacher evaluates awareness what teacher wants to raise }\end{array}$ \\
\hline
\end{tabular}




\section{Research Methodology}

The purpose of this study is to determine students' perceptions of $5 \mathrm{E}$ learning cycles to enhance their active learning and secondly to explore what is the impact of 5E learning cycles towards student's active learning. This study will employed participatory action research design. Action research designs "are systematic procedures used by lecturers (or other individuals in an educational setting) to gather quantitative and qualitative data to address improvements in their educational setting, their teaching and the learning of their students" (Creswell, 2002) [28]. Mixed method is a procedure to collect, analyse, and mixing both quantitative and qualitative methods in a single study or a series of studies to have a better understand of a research problem Creswell and Clark's, (2007) [29]. Creswell (2012)[30] has classified mixed methods research designs into six primary types in the context of education which are three sequential (explanatory, exploratory, and transformative) and three convergent or parallel (triangulation, nested, and transformative). Each varies in regard to its use of implementation approach (sequential or concurrent data collection procedures). Anyhow priority given to the qualitative and quantitative data (equal or unequal), whereby the data are analysed and integrated (separated, transformed, or connected), and notations of procedure.

Action research processes involve acting, observing, reflecting and revising plan of actions. The first phase of data collection will begin with gathering and documenting problems related to the issue of this study. In the second phase or the 'identifying' stage, more rigorous literature will be gathered to identify a meeting point between previous research and the issues faced. This phase involves 'fact finding', which enables the researchers to refine ideas about the general focus area and to prepare more systematic investigation" (Burns, 1999, p. 37) [31]. This followed by the planning of data collection methodology and procedure, identifying and finding suitable technique that may help the lecturer to provide a systematic feedback to enhance students' participation in Consumer Behaviour class. In this participatory action research, the researchers will be the participants of the study and will get involved with students to improve the teaching and learning processes.

\subsection{Data Collection Methods}

This study will utilize two research designs which are quantitative and qualitative approach. Data will be collected qualitatively from various sources from students' reflections, lecturer's reflections, peer feedback, lecturer's feedback, and focus group interview. It also involves Oral Presentation Rubrics of Assessment by the lecturer to evaluate student's performance. Rubrics develop an effective marketing tactics or strategies base on real marketing scenario.

Apart from that, for quantitative method, a survey will be developed using Google form and then, will be posted online. Two research questions were formulated for this online survey as below:

1. What are the students' perceptions of $5 E$ learning cycles to enhance their active learning?

2. What is the impact of $5 E$ learning cycles to student's active learning?

The data will be analysed using transcribe technique and regression analysis.

\subsection{Data Collection Procedures}

Data collection will involve three phases. In the first phase, a focus group of interview will be conducted to explore issues regarding passive learning among Consumer Behaviour students for 2 weeks. In the second phase, the action research cycles will be conducted. During these processes, Google form survey and observation technique will be used to determine students' engagement, exploration, explanation, elaboration and evaluation on the cases given to them.

Briefly, students will be asked to write weekly reflection on the issues given in the cases. Then they will post it online for the researchers and peers to review. In the following class, they will rewrite their 
reflection based on the comments received. Here, the students and the researcher will work collaboratively to give feedback to their peers and improve their reflections. Data from the participants' reflections and researchers' reflections will also be collected in this phase. Finally, in the third phase, another interview will be done to gather information about the overall process and to evaluate the effectiveness of the intervention and to identify challenges faced by them. Researcher's reflection will also be collected and analysed for its effectiveness.

\subsection{Sample and Sampling}

Unit of analysis of this study will be undergraduate students who will be enrolling in BPMM3013 Consumer Behaviour class with an estimation of 60 students. They will be divided into 10 groups of 6 students to form focus groups.

\section{Conclusion}

Generally, students and instructor come into contact to share information in their quest for knowledge. A conducive classroom environment involved two-way interaction between students and instructors. This type of classroom environment will stimulate learning and makes both the instructor and students feel satisfied, which eventually leads to effective learning process. Therefore, a guideline for good 5E learning cycle practice and strategies to help students to participate in Consumer Behavior class will be produced from this study. Also, a model of good 5E learning cycle practices will be produced.

\section{Acknowledgement}

Yaty Sulaiman, Maria Abdul Rahman and Nik Kamariah Nik Mat are Associate Professors and Professor of Marketing, School of Business Management, College of Business, Universiti Utara Malaysia 06010 Sintok, Kedah, Malaysia. The authors would like to thank the Ministry of Higher Education (MOHE) for granting this research under the Scholar of Teaching and Learning Grant Scheme (SOTL) and Research Innovation Management Centre (RIMC) Universiti Utara Malaysia. This article is under SOTL grant research, 2019 (S/O Code 14507). 


\section{References}

[1] Abdullah, M.Y., Bakar,A.\& Mahbob, M.H.(2012). Student's participation in classroom: What motivates them to speak up? Social and Behavioral Sciences, 51, 516-522.

[2] Ergin_I, Kanlı, U., and Tan M (2007). To examine the effects of $5 \mathrm{E}$ model on the students' academic success in physics education. Gazi Eg ittim Faku ltesi Dergisi 27 (2): 191-209.

[3]Torney-Purta, J., Lehmann, R., Oswald, H., \& Schulz, W. (2001). Citizenship and education in twenty-eight countries: Civic knowledge and engagement at age fourteen. Amsterdam, The Netherlands: International Association for the Evaluation of Educational Achievement.

[4] Wade, R. (1994). Teacher education students' views on class discussion: implications for fostering critical thinking. Teaching and Teacher Education. Vol. 10(2): 231-243.

[5] Senan, D. C. (2013). Infusing BSCS 5e instructional model with multimedia: A promising approach to develop 21st century skills. I managers' Journal on School Educational Technology, 9(22), 17.

[6] [7] [26] Duran, L. B., \& Duran, E. (2004). The 5E instructional model: A learning cycle approach for inquiry-based science teaching. Science Education Review, 3(2), 49- 58.

[8] Soon, Meng and Jiong (2017). Learning Mathematical Flexibility in a Constructivist 5E. Learning Mathematical Flexibility in a Constructivist 5E Model, 8 ICLLCE 2017-009.

[9] Mohd Yusof, et al. (2011). The Dynamics of Student Participation in Classroom: Observation on level and forms of participation. Paper presented at Learning and Teaching Congress of UKM, 18th20th. December, Penang, Malaysia.
[10] Hussein, G. (2010).The Attitudes of Undergraduate Students towards Motivation and Technology in a Foreign Language Classroom. International Journal of Learning and Teaching, 2 (2) 14-24.

[11] Bas, G. (2010). Effects of multiple intelligences instruction strategy on students achievement levels and attitudes towards english lesson. Cypriot Journal of Educational Sciences, 5(3).

[12] Davis, B. G. (2009). Tools for teaching (2nd.ed.). San Francisco: Jossey-Bass.

[13] Pajares, F. (1996). Assessing selfefficacy beliefs and academic success: the case for specificity and correspondence. Paper presented at the Annual Meeting of the American Educational Research Association, New York.

[14] Schunk, D. H. (1995). Self-efficacy and education and instruction. In Maddux (ed.), Self-efficacy, adaptation and adjustment: Th eory, research and application. New York: Plenum Press. Pp. 281-303.

[15] Rahil Mahyuddin, Habibah Elias, Loh Sau Cheong, Muhd Fauzi Muhamad, Nooreen Noordin \& Maria Cheong Abdullah. (2006). The relationship between students' self-efficacy and thier English language achievement. Jurnal Pendidik dan Pendidikan. Jil. 21: 61-71. Kuala Lumpur: Universiti Malaya.

[16] Siti Maziha Mustapha, Nik Suryani Nik Abd. Rahman \& Melor Md. Yunus. (2010). Factors influencing classroom participation: a case study of Malaysian undergraduate student. Procedia Social and Behavioral Sciences. Vol. 9: 10791084. WCLTA 2010.

[17] Fassinger, P. A. (1995). Professors' and students' perception of why students participate in class. Teaching Sociology. 24, 25-33. 
[18] Gomez, A. M. Arai, M. J. \& Lowe, H. (1995). When does a student participate in class? Ethnicity and classroom participation. Paper presented at the Annual Meeting of the Speech Communication Association (81st, San Antonio, TX).

[19] Cakir, N. K. (2017). Effect of 5E Learning Model on Academic Achievement, Attitude and

Science Process Skills: Meta-analysis Study. 2324-8068.

[20] Gillies RM. Structuring cooperative group work in classrooms. International Journal of Educational Research. 2003;39(1):3549.

[21] Kilavuz Y. The effect of 5E learning method based on conctructivist approac to the understanding of the concepts related to acids and bases of 10th graders. Post graduate Thesis, Institute of Science, Ankara; 2005.

[22] Bozdoğan AE, ve Altunçekiç A. Opinions of science teacher candidates about $5 \mathrm{E}$ teaching model usability. Kastamonu Education Journal. 2007;15(2):579-590.

[23] Hırça N. Anaylse of the effect of materials related to "Work, Power, Energy" developed according to 5E Model to Conceptual Change. Doctorate Thesis, Institute of Science, Erzurum; 2008.

[24] Wahyuni, Z., Syamsu, \& Muslimin. (2013). Penerapan Model Learning Cycle Tipe 5E dengan Media Visual Untuk Meningkatkan Hasil Belajar Fisika Pada Siswa Kelas Xc SMA Negeri 2 Dolo. Jurnal Pendidikan Fisika Tadulako, 1(1), 110.

[25] Supriyatman, \& Amiruddin, K. (2014). Implementation of Physics Learning
Material Based on the 4E Learning Cycle Method for Student SMP Negeri in Left Behind Area (Case Study in District Parigi Moutong). International Journal of Scientific Engineering and Research (IJSER), 2(2), 8-12.

[27] Senturk and Camliyer (2016). A New Learning Model on Physical Education: 5E Learning Cycle. Universal Journal of Educational Research, 4(1): 26-29.

[28] Creswell, J. W. (2002). Educational research: Planning, conducting, and evaluating quantitative and qualitative research. Boston, MA: Pearson Education

[29] Creswell, J. W., \& Clark, V. L. P. (2007). Designing and conducting mixed methods research. Thousand Oaks, CA: Sage Publications.

[30] Creswell, J.W. (2012). Educational research: Planning, conducting, and evaluating quantitative and qualitative research. (4th Ed.). Boston, MA: Pearson.

[31] Burns, A. (1999). Collaborative action research for English language teachers. Cambridge: Cambridge University Press.

\section{Creative Commons Attribution License 4.0 (Attribution 4.0 International, CC BY 4.0)}

This article is published under the terms of the Creative Commons Attribution License 4.0 https://creativecommons.org/licenses/by/4.0/de ed.en_US 